\title{
Parental Involvement and Children's Academic Achievement: In the Case of Some Selected Government Primary Schools of Bahirdar City, Ethiopia
}

\author{
Bezabih, Mezgebu Bayu \\ BA psychology, MA in developmental psychology
}

\begin{abstract}
The purpose of this study was to examine the relationship between parental involvement and academic achievement of children in some selected government primary schools of Bahirdar city. To achieve this objective, 180 sample students were selected by using simple random sampling technique. The collected data was analyzed through, spearman correlation, analysis of variance and independent-test. The finding of the study revealed that the statistical analysis on independent t-test showed that there was a statistically significant difference between male and female students with regard to their academic achievement $(t=6.25, \mathrm{df}=178, \mathrm{p}<0.05)$. The finding of spearman correlation indicates that there was significant relationship between parental involvement and academic achievement of students $(\mathrm{r}=.56, \mathrm{p}<.05)$. The result on one way ANOVA displayed that there was statistical significant difference among respondents academic achievement with regard to their parental level of education $(\mathrm{F} 2,176)=17.084, \mathrm{P}<0.05)$. In conclusion, parental involvement is positively correlated with academic achievement of students and males have better academic performance than their female counter parts.
\end{abstract}

Keywords: Parental involvement, Academic achievement, Children

DOI: $10.7176 / \mathrm{JEP} / 11-7-06$

Publication date:March $31^{\text {st }} 2020$

\section{Background of the study}

The effort of Parental involvement is an asset in students' academic achievement not only during elementary School alone, but also throughout secondary school (Henderson, 2002).

In relation to this,(Alexander KL. 1996.) figure out that,Parental involvement at home has a large and positive effect on students' academic achievement just beginning at primary level and the impact of this on students' academic achievement was much bigger than the impact of the school have, regardless of the parents education, income or family back ground.

Parental involvement in children's schooling experiences is becoming more and more viewed not simply as a complement to the work of educators, but as an important and crucial support for the academic, psychological, and emotional development of formative years. In research writing, there is an increasing perception of the possible of parent involvement to lift up the academic attainment of all students, for the creation of an integral part for school improvement initiatives (Jeynes, W.H, 2007)

The role of parental involvement has long been thought to be vital important to the academic achievement of their children. However, this role had neither been analyzed nor methodically studied using an experimental design until the 1960'sas study conducted by (AAU, 1995) indicates that Parental involvement can have a tremendous effect on the academic achievement of students. For example, a research conducted by Bronfenbrenner (1979) recognizes that, the importance role as strong positive bond between homes and schools play in the development and education of children. The researcher also tried to show that a good cooperation between schools, home and the community can lead the academic achievement of students. According to Epstein (as cited in Richardson, 2009), Parental involvement is the most powerful influence in children's education, because it can have various effects on students' both academically and behaviorally. In addition to that, children who are academically successful hold positive attitude at school and are well familiar emotionally and within society.

According to (Colbert, 1996) academic success of student is not due to the children's natural abilities and reflects the advantage of being in the family educational level and availability of facility.

Another study by Dearing et al., 2006; McWayne et al., 2004b) also forwarded as children who are economically advantaged (directly linked to their residence) receive enough stimulation at home thereby enhancing their academic achievement. Parents' high hope does have extra benefit over and above the recompense children enjoy from being capable and receiving adequate stimulation and resources. A bulk of researchers and research also indicates that higher level of parental aspiration lowered the likelihood of academic failure during primary school by $48 \%$ compared by the same token poor but low aspire parents (Dearing, E., Kreider, H., Simpkins, S., \& Weiss, H.B. (2006).

In recent studies, a combination of research on parent involvement in schooling reveals that all these evidences are consistent, positive, and convincing: Indicating that families have a major role on their children's success in school and throughout life (Desforges,C. and Abouchaar, A. (2003)This because when schools, families, 
and community work hand in hand jointly to support learning, children tend to do superior in school, stay at school longer, and be fond of school more.

Due to the sex differences, the psychological and physiological makeup of the student differs, male and female are raised differently and this may affect their academic success. Along this, by 1992, Vijayalaxmi and Natesan studied factors influencing academic success in the city of Coimbatore, 100 students studying in XI standard were selected for their study which includes 50 males and 50 females.

The main goal is in order to assess the academic achievement of the subjects; the total marks obtained by the subjects in quarterly and half yearly examination were taken. The findings confirm that males had a higher mean academic achievement compared to females.

The rate of parental involvement in their child's education is directly related with their level of education. Many researchers agree that regardless of race or culture, a parent's lack of education and/or low literacy level has a negative effect on involvement in his/her child's education. Additionally, parents' literacy skills and attitudes about learning and formal education can have an immense impact on their child's education. Because these parents can still encourage their child's education through non-traditional activities, but they may be incapable to help them in customary ways that enhance and support the school's education program (Taylor, 1993). This literature indicates that Children with parents who have received a high school education or higher are more likely to have parents who are highly involved in their schools.

Another study by Winquist (1998) reports informs that parents who have high expectations for their children's education were more likely to be parents with a high school education or better. In the mentioned research of 1993 study, children whose parents at least lacked a high school diploma were more likely kinds of children's who are to do poorly in school and more likely to drop out before graduating (Anderson, 2000). In Ethiopian context, general studies such as Father's Educational Involvement and Children's educational Aspiration, educational SelfConcept and academic achievement of Primary School Students (Mariamawit,2014), the relationship among parenting styles, academic self-concept, academic motivation and students' academic achievement in fasilo secondary school adolescents (Asrat, 2018) were conducted and none of them did not elucidate the relationship between parental involvement and academic achievement of students in a separate manner.

Taking the above gap in to account the current study focus on the relationship between parental involvement and academic achievement of primary school students.

\section{Objectives of the Study}

The main objective of this study was to examine the relation between parental involvement and children's academic achievement, whether there exists significant difference between male and female students with regard to their academic achievement or not and to examine whether significant difference exists between parental level of education and their children's academic achievement.

\section{Methods}

The study design was a correctional. This study was conducted in Bahirdar city four selected primary full cycle school students who are attending their education in the academic year of 2018/19. The population of this study is 1800. The sample size of the study was $180(10 \%)$ of the study population in which 97 are males and 83 are female students. Sample of the study population had been selected using simple random sampling technique. To collect the required data, Likert scale, items was adopted from previously conducted researches. The collected data was analyzed via quantitative method of data analysis that inculcated Spearman correlation coefficient, independent ttest, one way ANOVA and Post-Hock comparison (Tukey) was also used to identify which group of educational level was differing from which level.

\section{Result}

Table.1.Demographic Information of participants

\begin{tabular}{ccccccc}
\hline Grade level & Sex & \multicolumn{5}{c}{$\%$} \\
\hline Grade 7 & $M$ & $F$ & Total & $M$ & $F$ & $T$ \\
\hline Grade 8 & 40 & 45 & 85 & 47.05 & 52.94 & 100 \\
\hline Total & 57 & 38 & 95 & 60 & 40 & 100 \\
\hline
\end{tabular}

Table 1 showed that $83(46.11 \%)$ of female and 97 (53.88\%) male students were participated in the study.

Table. 2 Gender difference in relation to their academic achievement

\begin{tabular}{llllllll}
\hline Variable & Sex of respondents & $N$ & Mean & $S D$ & $d f$ & $t$ & Sig. \\
\hline Academic achievement & Male & 97 & 28.73 & 6.74 & 178 & \multirow{2}{*}{$6.47^{*}$} & \multirow{2}{*}{.000} \\
\cline { 2 - 5 } & Female & 83 & 17.08 & 5.17 & & & \\
\hline${ }^{\mathrm{p}<.05} \mathrm{M}=$ Mean & $\mathrm{SD}=$ Standard Deviation & $\mathrm{DF}=$ Degree of Freedom & & &
\end{tabular}


The statistical analysis on the above table revealed that there was a statistically significant difference between male and female students in their academic performance $(\mathrm{t}=6.47, \mathrm{df}=178, \mathrm{p}<0.05)$. Furthermore, descriptive statistics were also computed to find out the differences in academic performance by sex. As table 2 depicted, males had the mean of 27.73 with standard deviation of 6.74 and the mean of female students was 17.08 with standard deviation of 5.17. This implies that relatively males had better academic performance than their female counterparts

Table 3: Spearman correlation coefficient on parental involvement and academic achievement of students

\begin{tabular}{|c|c|c|c|}
\hline & & Academic achievement & parental involvement \\
\hline \multirow{3}{*}{ Academic achievement } & Pearson Correlation & & $.56^{* *}$ \\
\hline & & & .000 \\
\hline & & 179 & 179 \\
\hline \multirow{3}{*}{ parental involvement } & Pearson Correlation & $.56^{* *}$ & \\
\hline & & .000 & \\
\hline & & 179 & 180 \\
\hline
\end{tabular}

**. Correlation is significant at the 0.01 level (2-tailed).

Pearson product moment correlation was computed to see the relationship between parental involvement and students' academic achievement. The result revealed that there was positive relationship between the two variables at $\mathrm{r} .56 \mathrm{p}=.00$ ). This surprisingly implies that, as parental involvement was increased, students' academic achievement was also increased.

Table 4: Summary of One Way ANOVA for comparison children's academic achievement and parental educational level

\begin{tabular}{|c|c|c|c|c|c|c|}
\hline & Sum of square & df & Mean square & $\mathrm{F}$ & Sig & $\underline{F}$ \\
\hline Between groups & 6.111 & 2 & 3.055 & 17.084 & \multirow[t]{3}{*}{.000} & 17.084 \\
\hline Within groups & 31.476 & 176 & 179 & & & \\
\hline Total & 37.587 & 178 & & & & \\
\hline
\end{tabular}

$* \mathrm{P}<0.05 \mathrm{SS}=$ Sum Squares; MS = Mean Square; $\mathrm{Df}=$ degree of freedom

Further to identify participants parental education of which category is significantly differ, a post hoc test also called post-hoc comparison (Tukey) was run and the result is displayed as well as elaborated in the table in the next page.

Table: 5. Post-Hoc tests on parental level of education and children's academic achievement (Tukey)

\begin{tabular}{lllll}
\hline \multirow{3}{*}{$\begin{array}{l}\text { Variables } \\
\text { Academic } \\
\text { achievement }\end{array}$} & $\begin{array}{l}\text { (I) parental educational } \\
\text { level }\end{array}$ & $\begin{array}{l}(\mathrm{J}) \text { parental educational } \\
\text { level }\end{array}$ & $\begin{array}{l}\text { Mean } \\
\text { Difference(I-J) }\end{array}$ & \multirow{2}{*}{ Sig. } \\
& Basic education & High school complete & -1.564 & 4.55 \\
\cline { 2 - 5 } & & Diploma and above & $-6.115^{*}$ & .000 \\
\cline { 2 - 5 } & \multirow{2}{*}{ High school complete } & Basic education & 1.564 & .455 \\
\cline { 2 - 5 } & & Diploma and above & $-4.550^{*}$ & .004 \\
\cline { 2 - 5 } & \multirow{2}{*}{ Diploma and above } & Basic education & $6.115^{*}$ & .000 \\
\cline { 3 - 5 } & & High school complete & $4.550^{*}$ & .004 \\
\hline
\end{tabular}

*the mean difference is significant at $\mathrm{p}<0.05 \mathrm{As}$ the post Hoc result indicates the mean score of respondent's parents who had diploma and above educational level are significantly differ from parents who had attended both high school and basic education. On the other hand, those participants parents who had complete high school are significantly differ from parents from basic educational level in their involvement in to their children's achievement.

\section{Discussion}

The relationship between parental involvement and children's' academic achievement

Parental involvement had a positive and significant effect on children's overall academic achievement. Children gain better score and improve in academic achievement when their parents work hand in hand with school. The results of the present study also indicate parental involvement and students' academic achievement had very strong positive relationships. The finding of the study demonstrate that increased the potential of parental involvement is significantly related to a child's increased academic achievement.

This finding is Consistent with previous studies; parental involvement in child's education is consistently associated with child's academic performance (Jimerson and Teo, 1999).

Similarly study conducted by (Cooper, Lindsay \& Nye, 2000) on interviewing 268 fourth, fifth and sixth grade students also indicates that, when parents are capable of guiding the child and are inclined to supervise the home study, their children succeed in school.

Generally, parents' effort is consistently associated with higher level of achievement and the magnitude is also sustainable for high academic achievement. From this point view one can conclude that parents' involvement 
in their child's education is definitely important. It also creates a big difference among children on their academic achievement. This idea overwhelming indicates that there are positive academic outcome stemming from parental involvement with benefits from early age and later.

\section{Gender and Academic Achievement:}

Students' sex was also important variable that was expected to have influenced on students' academic achievement In view of this, an attempt was made to assess the academic achievement situation that exists between male and female students. Hence, an independent t-test is computed to see whether there is a real significant mean difference on academic achievement of male and female students. The result of this study revealed that male students were more likely better in scoring in their education than female students in this particular study. Thus, this implies that the two groups seem to be different in their overall academic achievement with males' academic achievement is better than female students' in the sample of study area. A similar study conducted by Vijayalaxmi, N. and Natesan, H., 1992, Factors influencing academic achievement. in the city of Coimbatore with 100 students studying in XI standard of 50 boys and 50 girls. The study also indicates that, the overall academic achievement of male had higher mean academic achievement as compared to girls.

\section{Comparison of children's academic achievement by Parental level of education}

One-way ANOVA was computed to see whether there was a statistically significant difference among the respondents academic achievement with regard to parental level of education. Thus, the statistical analysis disclosed that there is statistically significant difference $(\mathrm{F} 17.084, \mathrm{P}<0.05)$ parental levels of education that is basic education, high school complete and Diploma and above holders. Previous research findings by (Anderson, 2000) indicated that, children whose parents at least lacked a high school diploma were more likely kinds of children's who are to do poorly in school and more likely to drop out before graduating

\section{Conclusion}

Based on the finding of the study the following conclusions were drown

The study showed that Parental involvements have positive relationship with the children's academic achievement. Parental involvement is different across different educational level of parents. This means is that children's parents who have high educational level had also better involvement in their children academic achievement as compared to their less educated counterparts.

This study also revealed that significant gender difference is observed in academic achievement. The study also been insured the existence of strong relationship between parental level of education and student academic achievement, because, a significance difference had been observed on the grade achieved by students whose parents had high level of education and those students whose parents have low level of education

\section{Recommendation}

Depending on the findings of the study, the following recommendations were forwarded:

Parents should always enquire about the progress of their children.

School education board should mobilize parents to develop parent- teacher relationship to discuss about the academic improvement of the children.

\section{Declaration}

The undersigned, declare that this manuscript is my original work and all sources of material used for this manuscript have been duly acknowledged:

Mezgebu Bayu

\section{Acknowledgement}

I would like give my gratitude to participants who took part in this study. Without their genuine response, this study might not be successful. I would also thank my colleagues for supports and encouragements that they had done for me.

\section{Competing interest}

I declare that there is no competing interest

\section{References}

Alexander KL. 1996. Family and school link, How do they affect educational outcomes

Anderson, S. A.(2000). How parental involvement makes a difference in reading achievement. Reading Improvement, 37(2), 61.

Asrat Dagnew ( 2018) The relationship among parenting styles, academic self-concept, Academic motivation and 
students' academic achievement In fasilo secondary school, Research in Pedagogy, Vol.8, No.2,

Bronfenbrenner, U.(1979). Ecology of human development; experiments by nature and design. Cambridge: Harvard University press.

Colbert 1996, untapped resource, African parent perception on elementary schools guidance and counseling.

Cooper, Lindsay \& Nye, 2000): Fostering educational achievement in urban schools through school-familycommunity partnerships

Kohlberg, 1994, less educational involvement by families with high mobility, low SES and minority status.

Dearing, E., Kreider, H., Simpkins, S., \& Weiss, H.B. (2006). Family involvement in school and low-income children's literacy: Longitudinal association between and within families. Journal of Educational Psychology, 98, 653-664.

Desforges,C. and Abouchaar, A. (2003) The Impact of Parental Involvement, Parental Support and Family Education on Pupil Achievement and Adjustment: A Literature Review. (Research Report RR433), London, DfES.

Epstein, J.L. (2009). In School, family, and community partnerships: Your handbook for action(3rd ed.). USA: Corwin Press.

Griffith, 1991, Test of model of the organization, achievements of parent involvement and satisfaction with public education

Henderson, 2002, Positive Impacts of parent involvement child academic performance

Parent involvement conceptualizing multiple dimensions and their relationship with family and demographic risk factors. Published by University of Washington 2010.

Jimerson and Teo, (1999).Effect of home to school collaboration, Virginia.Teh.

ojs.academypublisher.com.N3387, Parent education and high school achievement

Jeynes, W.H. (2007). The relationship between parental involvement and urban secondary school student academic achievement: A meta-analysis. Urban Education,42(1), 82 - 110.

Mariamwit Girma ( 2014) Father's Educational Involvement and Children's Educational Aspiration, Educational Self-Concept and Academic Achievement of Primary School Students in Some Selected Schools of Addis Ababa. Addis Ababa University, unpublished master's thesis

Vijayalaxmi, N. and Natesan, H., 1992, Factors influencing academic achievement.ResHighlights, 2: 62.

Winquist, C. (1998). Factors associated with fathers' and mothers' involvement in their children's schools. (NCES 98-122). Washington, DC: National Center for Education Statistics. 